\title{
Capital Mobility in African Countries
}

\author{
Solo Padawassou ${ }^{1}$ \\ ${ }^{1}$ International Cultural Exchange School, Shanghai University of Finance and Economics, Shanghai, China \\ Correspondence: Solo Padawassou, Moto Sanili Mali, Avenue OUA Imm, Kolomina, BPE: 4006, Bamako, Mali. \\ Tel: 223-6355-5587. E-mail: letogolais002@hotmail.com \& International Cultural Exchange School, Shanghai \\ University of Finance and Economics, 369 Zhongshanbeiyi Road, Shanghai 200083, China. Tel: \\ 86-21-6536-1944. E-mail: hlwang@mail.shufe.edu.cn
}

Received: August 21, 2011

Accepted: April 12, 2012

Published: June 1, 2012

doi:10.5539/ijbm.v7n11p29

URL: http://dx.doi.org/10.5539/ijbm.v7n11p29

\begin{abstract}
It is well known that one of the important aspects of achieving sustainable development is to preserve macroeconomic stability, which is closely related to the extent of capital mobility. Given the importance of the subject for open economies, this paper examines the degree of capital mobility for African countries by using among other methodologies the Feldstein- Horioka coefficients. To determine those coefficients, we use time series data and methods, along with the Dynamic Heterogeneous panel approach. We find significant cross-country heterogeneity in the dynamic of income per capita, investment rate, and saving rate; and conclude that it is invalid to pool data across our sample countries. Furthemore, the empirical findings reveal that for African countries included in the sample, the estimated saving retention coefficients are at the same time, small and high indicating respectively higher and lower degrees of capital mobility and therefore, challenging the results of Feldstein - Horioka on developing countries.
\end{abstract}

Keywords: capital mobility, F-H puzzle, heterogeneity, panel unit roots, Johansen Maximum Likelihood (ML) approach

\section{Introduction}

To achieve sustainable development, it is quite important to sustain macroeconomic stability, which is closely related to the extent of capital mobility allowed by an economy. For this reason, measuring the level of capital mobility is an important task to achieve. While higher capital mobility was encountered as one of the reasons behind the recent worldwide financial crisis, the subject is also important for policy and firms for a number of reasons; (i) the effectiveness of macroeconomic policies is closely related to the degree of international capital mobility; (ii) higher international capital mobility helps firms to allocate resources efficiently and achieve risk diversification; (iii) higher international capital mobility may also increase volatility which may end up with financial crisis. For example, the global financial crisis began in the USA and spread to Europe and then to the whole world. Therefore, we realize that devastating effect of global financial crisis is more important in developed countries than developing countries.

In the economics literature, the presence of capital mobility is tested alternatively by using the saving-investment correlation, interest parity condition, and finally the consumption - smoothing approach to the current account. In this regard, one of the famous international macroeconomic hypotheses that is concerned with the presence or absence of mobility of capital is the Feldstein-Horioka Hypothesis (1980), which states that in the absence of capital mobility, domestic saving and investment are highly correlated since investment is financed by domestic saving. On the other hand, provided that saving depends on the inter-temporal consumption decision and capital is highly mobile in an open economy, domestic savings will be globally very responsive to higher real rate of return and thus the country can finance its investment by foreign savings. Contrary to the maintained assumption that in the developed countries, which are generally open-economies and where capital is highly mobile, Feldstein-Horioka (1980) presented econometric evidence showing that in a cross-section consisting of 16 OECD countries for the period 1960-1974, saving and investment are highly correlated indicating that capital is not mobile. Hence this finding is known as the Feldstein- Horioka (F-H) Puzzle. The present paper attempts to employ time series data and methods, along with the Dynamic Heterogeneous panel approach, to empirically assess the validity of the F-H puzzle using a panel of 22 African countries. In compliance with the interpretation 
made by F-H, small coefficients will be seen as high capital mobility.

The remaining of this paper is organized as followed: in section 2 we set up the literature review on international capital mobility; in section 3 we provide the sources of Data; in section 4 we give evidence of heterogeneity; in section 5 we outline the estimation methods; in section 6 we spread out the results and conclude in section 7 .

\section{Literature Review}

The prevalence of capital mobility among countries has many interesting economic implications for optimization of savings, efficacy of fiscal and monetary policy actions and the speed of convergence of countries to the steady-state economic growth. Given the importance of the subject for open economies, a number of different empirical methodologies (saving-investment correlation, interest parity condition, and the consumption -smoothing approach to the current account) were developed aiming to measure the extent of capital mobility. The F-H model has found widespread use in the empirical literature because the model is simple as well as providing an intuitive explanation for the level of capital mobility.

Using data over 1960-74, F-H (1980) found that the savings-retention coefficient is very close to one for 16 OECD countries, implying low capital mobility. Since then, an enormous literature has accumulated to test the F-H puzzle and explain the puzzle. In general, the empirical literature on the subject provides mixed results for both developed and developing countries.

A survey of the literature in this area reveals that there have been many empirical attempts to test the F-H Puzzle (hereafter, FH-puzzle) for OECD countries; Murthy (2005), Coakley, et al. (2004), Hoffman (2004), Sinha (2004), Ho (2003), Banerjee and Zanghieri (2003), Obstfeld and Rogoff (2000), Coakley, et al. (1998) and Jansen (1996, 1998)) and a recent study on the Asian economies by Kim et al. (2005). Ozmen (2005), Bahami-Oskooee and Chakrabarati(2005), and Sinha and Sihna (2004) find that the correlation between saving and investment is high in larger economies.

Some studies test the puzzle for developing countries and found out that the saving retention coefficient is small, indicating that the level of capital mobility is high in these countries (Payne and Kumazawa, 2006; Apergis and Tsoumas, 2009; Coakley et.al., 1999). On the contrary, other studies provide evidence that capital mobility is low in developing countries (Murthy, 2008; Ghosh and Ostry, 1995). While Wong (1990) argues that the high capital mobility observed in developing countries can be attributed to the size of the non-traded sector, Kasuga (2004) argues that small-sized and inefficient financial mechanisms in developing countries lead to high capital mobility.

Bangake and Eggoh (2010) mention the importance of the legal protection system provide for investors in relation to capital mobility. They tested the F-H puzzle for 37 African countries using the panel cointegration technique and found that savings and investment are a non-stationary and cointegrating series. Their estimation results indicate that capital mobility is higher (0.34) in countries with strong legal protection of investors than in countries with worse protection (0.85). Overall, the test of the F-H puzzle for the developing countries, including Middle East countries, shows high capital mobility because the magnitude of foreign aid and the extent of the non-traded sector are high in these countries and they have weak financial markets and are relatively open economies (Apergis and Tsoumas, 2009).

Studies which exclusively deal with capital mobility in Sub-Saharan Africa, have been undertaken by Payne and Kumazawa (2005) and De Wet and Van Eyden (2005). These afore-mentioned studies use the panel data for the period 1980-2000, but they do not undertake time series data and methods, along with the Dynamic Heterogeneous panel approach to deal with the concerns surrounding the panel and cross-country regressions. In order to fill in the void, the present paper attempts to employ time series data and methods, along with the Dynamic Heterogeneous panel approach to empirically assess the validity of the F-H puzzle using a panel of 22 African countries over a minimum of 28 (Gabon) to a maximum of 40 (South Africa) years.

\section{Data}

This paper attempts to investigate the relationship between investment rate and saving rate to measure the level of international capital mobility for African countries. The heterogeneity in the sample period across countries is mainly due to the lack of data. Data on gross savings as share of GDP and gross investment as share of GDP are obtained from Online World Development indicators data base, 2010. Data frequency, determined simply by data availability, is annual and the sample period is: $1974-2005$ for Madagascar, Senegal, and Togo; $1974-2008$ for Benin; 1975 - 2006 for Ghana; 1975 - 2007 for Mali; 1975 - 2009 for Botswana, Cote d'Ivoire, Kenya, and Morocco; 1976 - 2009 for Mauritius, Seychelles, and Tunisia; 1977 - 2009 for Egypt, Sierra-Leone, and Sudan; 1978 - 2005 for Gabon; 1978 - 2007 for Congo; and 1980 - 2009 for Mozambique and Uganda. 
In table 1 where descriptive statistics of data are plotted, Botswana is the fastest growing economy ( $4.9 \%$ growth of real capita income per annum) and Cote d'Ivoire the slowest (- 1,6\%). Comparing performances between the first 5 years and the last 5 years for each country, Uganda has the highest growth rate of savings while Mozambique the lowest. The saving rate of Uganda grows about 233\% and that one of Mozambique falls off about $282 \%$. At the same period, the investment rate of Uganda has grown about $209 \%$ and the investment rate of Mozambique about $72 \%$. These performances are far away bigger than the whole sample performances which are about $13.2 \%$ for saving rate and $18.2 \%$ for investment rate.

Table 1. Summary statistics

\begin{tabular}{|c|c|c|c|c|c|c|c|}
\hline \multirow[t]{2}{*}{ Country } & \multirow{2}{*}{$\begin{array}{l}\text { Growth of } \\
\text { Real per } \\
\text { capita GDP }\end{array}$} & \multicolumn{2}{|c|}{$\begin{array}{l}\text { Gross Investment } \\
\operatorname{GDP}(\mathrm{S} / \mathrm{Y})\end{array}$} & \multirow{2}{*}{$\begin{array}{l}\text { share of } \\
\text { SMV }\end{array}$} & \multicolumn{2}{|c|}{$\begin{array}{l}\text { Gross Savings as } \\
\text { GDP (I/Y) }\end{array}$} & \multirow{2}{*}{$\begin{array}{l}\text { share of } \\
\text { SMV }\end{array}$} \\
\hline & & F 5-Y & L 5-Y & & F 5-Y & L 5-Y & \\
\hline Benin & 0.005 & 17.600 & 19.625 & 16.980 & 11.316 & 9.244 & 7.941 \\
\hline Botswana & 0.049 & 36.544 & 26.519 & 30.091 & 26.374 & 34.942 & 35.095 \\
\hline Cameroon & 0.006 & 27.286 & 18.002 & 20.022 & 10.740 & 17.623 & 15.890 \\
\hline Congo, Rep. & 0.015 & 39.391 & 24.426 & 27.717 & 23.292 & 13.951 & 15.923 \\
\hline Cote d'Ivoire & -0.016 & 26.099 & 9.825 & 14.578 & 18.775 & 11.506 & 9.709 \\
\hline Egypt & 0.028 & 30.140 & 19.841 & 23.580 & 21.934 & 21.745 & 22.463 \\
\hline Gabon & -0.009 & 33.368 & 23.976 & 29.100 & 44.018 & 36.221 & 33.206 \\
\hline Ghana & 0.007 & 8.917 & 24.330 & 15.448 & 9.674 & 19.890 & 12.297 \\
\hline Kenya & 0.005 & 21.986 & 19.033 & 20.139 & 17.494 & 15.570 & 18.160 \\
\hline Madagascar & -0.014 & 8.519 & 19.246 & 12.504 & 5.976 & 12.382 & 5.697 \\
\hline Mali & 0.016 & 15.173 & 22.619 & 20.025 & 9.150 & 13.462 & 11.008 \\
\hline Mauritius & 0.035 & 28.567 & 24.912 & 25.927 & 18.945 & 17.846 & 22.668 \\
\hline Morocco & 0.022 & 27.404 & 32.960 & 25.832 & 16.522 & 31.902 & 23.099 \\
\hline Mozambique & 0.023 & 10.366 & 17.826 & 17.987 & -3.698 & 6.731 & 3.877 \\
\hline Senegal & 0.002 & 16.461 & 21.395 & 16.030 & 11.836 & 15.246 & 8.128 \\
\hline Seychelles & 0.022 & 38.695 & 25.999 & 28.427 & 35.512 & 3.447 & 21.567 \\
\hline Sierra Leone & 0.001 & 15.133 & 15.044 & 10.588 & 5.390 & 8.486 & 5.722 \\
\hline South Africa & 0.003 & 28.171 & 20.060 & 20.832 & 25.588 & 14.647 & 20.030 \\
\hline Sudan & 0.017 & 15.510 & 28.018 & 17.233 & 6.004 & 15.667 & 6.889 \\
\hline Togo & -0.006 & 31.189 & 18.837 & 21.079 & 37.026 & 8.238 & 16.656 \\
\hline Tunisia & 0.027 & 30.150 & 24.694 & 27.302 & 24.917 & 21.365 & 22.852 \\
\hline Uganda & 0.026 & 7.281 & 22.482 & 15.277 & 5.603 & 18.636 & 12.507 \\
\hline Average Change & 0.012 & 0.182 & & & 0.132 & & \\
\hline
\end{tabular}

Growth of Real Per Capita GDP indicates the average annual growth rate over the sample period. Subscripts F5 - Y and L5 - Y denote mean values of the first 5 years and the last 5 years of the sample for each country, subscript SMV denotes the sample mean value. The average change in the last raw is calculated as: $\sum_{1}^{22}\left(\left(X_{L 5-Y}-X_{F 5-Y}\right) / X_{F 5-Y}\right) / 22$ where $X$ represents $(\mathrm{S} / \mathrm{Y})$ and $(\mathrm{I} / \mathrm{Y})$. 
Generally, countries which have positive rate of saving have also positive rate of investment. But this is not a rule since Benin has negative rate of saving and at the same time positive rate of investment. Similarly, Botswana and Cameroon which have positive rate of savings hold negative rate of investment.

\section{Heterogeneity}

Our sample is composed of low and middle income countries. From table 1 were data statistics are plotted, countries represent different stage of development, different investments, and different savings policy. As there is concern of growth, saving, and investment about the panel and cross-section tests, it is necessary to previously test whether it is valid to pool data set of these economies. Formal tests of the dynamic heterogeneity of the investment rate and saving rate are conducted as followed:

We use two aspects of residual tests: Breusch-Godfrey Serial Correlation LM Tests and Heteroskedasticity Tests. From the both aspects, as plotted in table 2, all of the F-Statistics are bigger than the F-statistics read from Fisher and Snedecor table and (n*R-squared) is higher in all specifications than the relative Chi-squared read from the table. From these results, the tests reject the null hypothesis under all specifications. Specifically, the LM test confirms that error variances across sample countries are significantly different and this also holds across all specifications. It follows that the elasticity of $(I / Y)_{i t}$ with respect to $(S / Y)_{i t}$ is heterogeneous across countries. Also, the error dynamics across sample countries are significantly heterogeneous. Consequently the data set cannot be pooled.

Table 2. Heterogeneity tests

\begin{tabular}{|c|c|c|c|c|c|}
\hline \multicolumn{6}{|c|}{ Breusch-Godfrey Serial Correlation LM Test: } \\
\hline F-statistic & 313.8618 & 125.1844 & 90.6998 & 63.8157 & 43.1578 \\
\hline Obs*R-squared & 336.9987 & 337.2339 & 340.3011 & 341.9820 & 345.8385 \\
\hline Probability & 0.0000 & 0.0000 & 0.0000 & 0.0000 & 0.0000 \\
\hline DOF & $\mathrm{F}(2,719)$ & $\mathrm{F}(5,716)$ & $\mathrm{F}(7,714)$ & $\mathrm{F}(10,711)$ & $\mathrm{F}(15,706)$ \\
\hline \multicolumn{6}{|c|}{ Heteroskedasticity Test: } \\
\hline & B-P-G & Glejser & White & Arch & Arch \\
\hline F-statistic & 12.3498 & 7.5008 & 30.8189 & 59.8162 & 26.4041 \\
\hline Obs*R-squared & 12.1755 & 7.4441 & 57.0138 & 102.9748 & 112.3085 \\
\hline Probability & 0.0005 & 0.0063 & 0.0000 & 0.0000 & 0.0000 \\
\hline DOF & $\mathrm{F}(1,721)$ & $\mathrm{F}(1,721)$ & $\mathrm{F}(2,720)$ & $\mathrm{F}(2,718)$ & $\mathrm{F}(5,712)$ \\
\hline
\end{tabular}

DOF: Degree of freedom; obs = number of observations; B-P-G: Breusch-Pagan-Godfrey

\section{Model Specification and Econometric Methodology}

\subsection{Specification}

In order to ascertain the presence of a long-run equilibrium relationship between the investment rate (I/Y) and the saving rate $(\mathrm{S} / \mathrm{Y})$; the model suggested and empirically estimated by Feldstein and Horioka (1980) is as followed:

$$
(I / Y)_{i t}=\alpha_{i}+\beta_{i}(S / Y)_{i t}+\varepsilon_{i t}
$$

$i=1, \ldots . N$ and $\mathrm{t}=1, \ldots, T . I, S$, and $Y$ represent respectively, domestic investment, domestic saving, and gross domestic product. The coefficients $\alpha_{i}$ and $\beta_{i}$ denote respectively constant term and saving retention coefficients. In equation (1), the dependent variable (domestic investment) and the independent variable (domestic saving) are given as shares of the gross domestic product. Using data over 1960-74, Feldstein and Horioka (1980) found that the saving retention coefficient is very close to one for 16 OECD countries, implying low capital mobility. For the purpose of this paper, we are more interested in the significance of the coefficient $\beta$, rather than its sign. 
It is common that cross-section studies use several other factors influencing the investment rate for instance, political stability, efficiency of financial mechanisms, the importance of the legal right system provided for investors, human capital, indicators of corruption, taxes etc. We recall that the specification (1) compares favorably with the model suggested by F-H.

\subsection{Econometric Methodology}

Under the Johansen (1988) maximum likelihood (ML) approach, a k-dimensional and $\mathrm{p}^{\text {th }}$ order vector $(X)$ can be re-parameterized to a vector error correction model (VECM):

$$
\Delta X_{t}=\mu+\Gamma_{1} \Delta X_{t-1}+\Gamma_{2} \Delta X_{t-2}+\ldots+\Gamma_{p-1} \Delta X_{t-p+1}+\Pi X_{t-p}+\varphi D_{t}+\varepsilon_{t}
$$

In our analysis, $X_{t}[I / Y, S / Y]$ is a $2 \times 1$ vector of first-order integrated $[I(1)]$ variables, $\Gamma_{i}$ are $(2 \times 2)$ short run coefficient matrices; $\Pi_{(2 \times 2)}$ is a matrix of long run (level) parameters; $D_{t}$ captures the usual deterministic components; $\mu$ is a constant term and $\varepsilon_{t}$ is a vector of Gaussian error. A co-integrated system, $X_{t}$, implies that: (i) $\Pi=\alpha_{(2 x)} \beta^{\prime}{ }_{(x 2)}$ is rank deficient, i.e. $r<k(\mathrm{r}=$ number of distinct co integrating vectors; $\mathrm{k}=2)$; and (ii) $\{\alpha \perp \Gamma \beta \perp\}$ has full rank, $(\mathrm{k}-\mathrm{r})$, where $\alpha \perp$ and $\beta \perp$ are $(2 \mathrm{x}(2-\mathrm{r}))$ orthogonal matrices to $\alpha$ and $\beta$. The rank of $\Pi$ is tested by Maximal Eigen value $(\lambda-\max )$ and Trace statistics (Johansen, 1988).

The Johansen method is a reduced-form dynamic system estimator, which addresses the issues of multi co-integration and normalization. A number of issues are important for the estimation of the VAR model. It is the time span of data rather than the number of observations, which determines the power of co-integration tests (Campbell and Pearson, 1991). Our data extend from a minimum of 28 (Gabon) to a maximum of 40 (South Africa) years, which we suppose, can provide sufficient time length to capture the long-run relationship between $(\mathrm{I} / \mathrm{Y})$ and $(\mathrm{S} / \mathrm{Y})($ Note 1$)$ We specify the VAR lengths $(\mathrm{p})$ such that the VAR residuals are rendered non-autocorrelated(Note 2) A constant term is entered in the co-integrating space to allow for non-zero mean of the system variables. A trivariate VAR can exhibit two co-integrating vectors at the most. Pesaran and Shin (2002) suggest identification of multi-cointegration through the tests of over identifying restrictions. We follow their approach of identification if multiple co-integrating vectors are found.

\section{Results}

In order to evaluate the time series properties of the data formally, we implement the Phillips-Perron stationary test statistic, which tests the null of stationary. The results are reported in table 3. (I/Y) and $(\mathrm{S} / \mathrm{Y})$ are non-stationary, tests reject the null of stationary in all cases at levels. The both series appear unequivocally stationary in their first differences, so the finding of the Phillips-Perron test statistic is that $(\mathrm{I} / \mathrm{Y})$ and $(\mathrm{S} / \mathrm{Y})$ are $\mathrm{I}(1)$.

Note that evidence in favor of a stationary current account or cointegration of saving and investment can be interpreted in two diametrically opposing manners. On one hand it can be interpreted as confirmation of the FH result; on the other it can be interpreted as evidence of open capital markets imposing a solvency constraint on countries. The empirical evidence on the stationarity of the current account employing conventional cointegration techniques is mixed (Miller, 1988; Gulley, 1992; Gundlach and Sinn, 1992; Argimo'n and Rolda'n, 1994; Ghosh, 1995). Some recent approaches have employed panel unit root tests to test for the stationarity of the current account (Coakley et al., 1996a,b; Krol, 1996; Coakley and Kulasi, 1997). The panel tests of Im et al. (1995) have higher power than individual, pair wise tests and the general conclusion is that the current account is a stationary series in both in developing and OECD countries. 
Table 3. Phillips-Perron stationary test statistic

\begin{tabular}{|c|c|c|c|c|}
\hline \multirow[t]{2}{*}{ Levels } & \multicolumn{2}{|l|}{$\mathrm{I} / \mathrm{Y}$} & \multicolumn{2}{|l|}{$\mathrm{S} / \mathrm{Y}$} \\
\hline & Intercept & Trend \& intercept & Intercept & Trend \& intercept \\
\hline Benin & $-3.501731^{c}$ & $-3.693904^{c}$ & -4.147669 & $-4.116588^{c}$ \\
\hline Botswana & $-3.042764^{c}$ & $-3.244372^{b}$ & $-1.754372^{a}$ & $-1.270131^{a}$ \\
\hline Cameroon & $-1.720717^{a}$ & $-1.613612^{a}$ & $-3.494422^{c}$ & $-3.523483^{b}$ \\
\hline Congo & $-2.218749^{a}$ & $-2.507241^{a}$ & $-2.671701^{b}$ & $-2.96281^{a}$ \\
\hline Cote d'Ivoire & $-1.393004^{a}$ & $-1.601982^{a}$ & $-2.006561^{a}$ & $-1.909066^{a}$ \\
\hline Egypt & $-1.355643^{a}$ & $-2.198409^{a}$ & $-2.437184^{a}$ & $-2.386039^{b}$ \\
\hline Gabon & $-2.826297^{b}$ & $-3.635676^{c}$ & $-1.946566^{a}$ & $-1.738482^{a}$ \\
\hline Ghana & $-1.195118^{a}$ & $-2.640558^{a}$ & $-2.341427^{a}$ & $-3.747293^{c}$ \\
\hline Kenya & $-3.154267^{c}$ & $-4.251704^{c}$ & -3.769445 & $-3.82682^{c}$ \\
\hline Madagascar & $-1.295662^{a}$ & $-2.715823^{a}$ & $-2.490314^{a}$ & $-3.227642^{b}$ \\
\hline Mali & $-2.488297^{a}$ & $-3.777605^{c}$ & $-2.428497^{a}$ & $-3.083541^{a}$ \\
\hline Mauritius & $-2.813133^{b}$ & $-2.785708^{a}$ & $-1.79278^{a}$ & $-1.7704^{a}$ \\
\hline Morocco & $-0.798895^{a}$ & $-0.911765^{a}$ & $-0.686969^{a}$ & $-3.086427^{a}$ \\
\hline Mozambique & $-2.729172^{b}$ & $-2.907579^{a}$ & $-3.621383^{c}$ & -5.679832 \\
\hline Senegal & $-0.876253^{a}$ & $-1.405511^{a}$ & $-1.540934^{a}$ & $-2.926342^{a}$ \\
\hline Seychelles & $-2.963108^{c}$ & $-2.936739^{a}$ & $-1.115784^{a}$ & $-3.081704^{a}$ \\
\hline Sierra Leone & $-2.091107^{a}$ & $-1.738097^{a}$ & $-3.220026^{c}$ & $-3.15497^{a}$ \\
\hline South Africa & $-1.534667^{a}$ & $-2.215328^{a}$ & $-1.234854^{a}$ & $-3.294941^{b}$ \\
\hline Sudan & $-1.326063^{a}$ & $-1.97107^{a}$ & $-2.102714^{a}$ & $-3.002636^{a}$ \\
\hline Togo & $-2.292499^{a}$ & $-2.993323^{a}$ & -4.575702 & -6.104609 \\
\hline Tunisia & $-2.226245^{a}$ & $-2.586549^{a}$ & $-3.508432^{b}$ & $-3.957517^{c}$ \\
\hline Uganda & $-0.859904^{a}$ & -5.078755 & $-1.929875^{a}$ & $-3.191486^{a}$ \\
\hline
\end{tabular}

Intercept and trend \& intercept test the nulls of level and trend stationary. Subscripts a, b, and c indicate rejection of the null of stationary at $1 \%, 5 \%$, and $10 \%$, respectively.

Table 4 reports the Johansen rank tests and a range of VAR diagnostics obtained from the Error Correction Model (ECM). Trace tests show that (I/Y) and (S/Y) are co-integrated and exhibit a single rank (vector) for all sample countries. This is also supported by the maximal Eigen value statistics. So, given the superiority of trace statistics over the maximal Eigen value statistics in testing the null of no co-integration, we conclude that (I/Y) and $(\mathrm{S} / \mathrm{Y})$ are co-integrated with single co-integrating vector for all of our sample countries. 
Table 4. Co-Integration tests and VAR diagnostics between GI and GS (Johansen Method)

\begin{tabular}{|c|c|c|c|c|c|c|c|c|}
\hline \multirow[t]{2}{*}{ Country } & \multicolumn{2}{|c|}{ Trace Statistics,H0 } & \multicolumn{2}{|c|}{$\begin{array}{l}\text { Max Eigen value, } \\
\text { H0 }\end{array}$} & \multirow[t]{2}{*}{$\begin{array}{l}\text { Loading } \\
\text { Factor }\end{array}$} & \multirow[t]{2}{*}{$\operatorname{LM}(3)$} & \multirow[t]{2}{*}{ Nor } & \multirow[t]{2}{*}{ Lag } \\
\hline & $r \leq 0$ & $r \leq 1$ & $r \leq 0$ & $r \leq 1$ & & & & \\
\hline Benin & $\begin{array}{l}21.693 * \\
(0.017)\end{array}$ & $\begin{array}{l}4.396 * \\
(0.036)\end{array}$ & $\begin{array}{l}17.297 * \\
(0.048)\end{array}$ & $\begin{array}{l}4.396^{*} \\
(0.036)\end{array}$ & $\begin{array}{l}-0.577^{a} \\
(0.165)\end{array}$ & 0.129 & 0.207 & 2 \\
\hline Botswana & $\begin{array}{l}15.353 \\
(0.127)\end{array}$ & $\begin{array}{l}2.217 \\
(0.137)\end{array}$ & $\begin{array}{l}13.136 \\
(0.175)\end{array}$ & $\begin{array}{l}2.217 \\
(0.137)\end{array}$ & $\begin{array}{l}-0.319^{b} \\
(0.140)\end{array}$ & 0.760 & 0.845 & 3 \\
\hline Cameroon & $\begin{array}{l}11.687 \\
(0.173)\end{array}$ & $\begin{array}{l}2.740 \\
(0.098)\end{array}$ & $\begin{array}{l}8.947 \\
(0.291)\end{array}$ & $\begin{array}{l}2.740 \\
(0.098)\end{array}$ & $\begin{array}{l}-0.188^{b} \\
(0.082)\end{array}$ & 0.837 & 0.164 & 2 \\
\hline Cote d'Ivoire & $\begin{array}{l}29.754^{*} \\
(0.001)\end{array}$ & $\begin{array}{l}5.654^{*} \\
(0.017)\end{array}$ & $\begin{array}{l}24.100 * \\
(0.004)\end{array}$ & $\begin{array}{l}5.654 * \\
(0.017)\end{array}$ & $\begin{array}{l}-0.136^{b} \\
(0.066)\end{array}$ & 0.169 & 0.087 & 3 \\
\hline Congo & $\begin{array}{l}14.874 \\
(0.145)\end{array}$ & $\begin{array}{l}5.194 * \\
(0.023)\end{array}$ & $\begin{array}{l}9.680 \\
(0.427)\end{array}$ & $\begin{array}{l}5.194 * \\
(0.023)\end{array}$ & $\begin{array}{l}-0.317^{c} \\
(0.159)\end{array}$ & 0.810 & 0.025 & 3 \\
\hline Egypt & $\begin{array}{l}17.478 \\
(0.067)\end{array}$ & $\begin{array}{l}6.411 * \\
(0.011)\end{array}$ & $\begin{array}{l}11.067 \\
(0.307)\end{array}$ & $\begin{array}{l}6.411 * \\
(0.011)\end{array}$ & $\begin{array}{l}-0.151 \\
(0.095)\end{array}$ & 0.546 & 0.217 & 3 \\
\hline Gabon & $\begin{array}{l}15.439 \\
(0.124)\end{array}$ & $\begin{array}{l}5.287 * \\
(0.022)\end{array}$ & $\begin{array}{l}10.151 \\
(0.383)\end{array}$ & $\begin{array}{l}5.287^{*} \\
(0.022)\end{array}$ & $\begin{array}{l}-0.668^{a} \\
(0.160)\end{array}$ & 0.314 & 0.173 & 3 \\
\hline Ghana & $\begin{array}{l}17.898 \\
(0.059)\end{array}$ & $\begin{array}{l}8.718 * \\
(0.003)\end{array}$ & $\begin{array}{l}9.180 \\
(0.477)\end{array}$ & $\begin{array}{l}8.718 * \\
(0.003)\end{array}$ & $\begin{array}{l}-0.255^{c} \\
(0.137)\end{array}$ & 0.695 & 0.029 & 1 \\
\hline ken & $\begin{array}{l}20.501 * \\
(0.025)\end{array}$ & $\begin{array}{l}4.914^{*} \\
(0.026)\end{array}$ & $\begin{array}{l}15.586 \\
(0.083)\end{array}$ & $\begin{array}{l}4.914 * \\
(0.026)\end{array}$ & $\begin{array}{l}-0.451^{a} \\
(0.149)\end{array}$ & 0.751 & 0.431 & 2 \\
\hline Madagascar & $\begin{array}{l}21.348^{*} \\
(0.019)\end{array}$ & $\begin{array}{l}7.957 * \\
(0.005)\end{array}$ & $\begin{array}{l}13.392 \\
(0.162)\end{array}$ & $\begin{array}{l}7.957^{*} \\
(0.005)\end{array}$ & $\begin{array}{l}-0.317^{b} \\
(0.150)\end{array}$ & 0.563 & 0.136 & 2 \\
\hline Mali & $\begin{array}{l}10.502 \\
(0.433)\end{array}$ & $\begin{array}{l}4.554 * \\
(0.033)\end{array}$ & $\begin{array}{l}5.948 \\
(0.822)\end{array}$ & $\begin{array}{l}4.554 * \\
(0.033)\end{array}$ & $\begin{array}{l}-0.524^{a} \\
(0.161)\end{array}$ & 0.642 & 0.007 & 3 \\
\hline Mauritius & $\begin{array}{l}13.355 \\
(0.220)\end{array}$ & $\begin{array}{l}5.301 * \\
(0.021)\end{array}$ & $\begin{array}{l}8.054 \\
(0.597)\end{array}$ & $\begin{array}{l}5.301 * \\
(0.021)\end{array}$ & $\begin{array}{l}-0.527^{a} \\
(0.154)\end{array}$ & 0.973 & 0.524 & 3 \\
\hline Morocco & $\begin{array}{l}12.140 \\
(0.150)\end{array}$ & $\begin{array}{l}1.701 \\
(0.192)\end{array}$ & $\begin{array}{l}10.439 \\
(0.185)\end{array}$ & $\begin{array}{l}1.701 \\
(0.192)\end{array}$ & $\begin{array}{l}-0.220^{c} \\
(0.123)\end{array}$ & 0.224 & 0.033 & 1 \\
\hline Mozambique & $\begin{array}{l}15.837^{*} \\
(0.044)\end{array}$ & $\begin{array}{l}3.457 \\
(0.063)\end{array}$ & $\begin{array}{l}12.380 \\
(0.097)\end{array}$ & $\begin{array}{l}3.457 \\
(0.063)\end{array}$ & $\begin{array}{l}-0.459^{b} \\
(0.172)\end{array}$ & 0.581 & 0.658 & 3 \\
\hline Senegal & $\begin{array}{l}12.289 \\
(0.144)\end{array}$ & $\begin{array}{l}0.417 \\
(0.519)\end{array}$ & $\begin{array}{l}11.873 \\
(0.116)\end{array}$ & $\begin{array}{l}0.417 \\
(0.519)\end{array}$ & $\begin{array}{l}-0.177 \\
(0.115)\end{array}$ & 0.607 & 0.115 & 4 \\
\hline Seychelles & $\begin{array}{l}15.371 \\
(0.126)\end{array}$ & $\begin{array}{l}6.921 * \\
(0.008)\end{array}$ & $\begin{array}{l}8.450 \\
(0.554)\end{array}$ & $\begin{array}{l}6.921^{*} \\
(0.008)\end{array}$ & $\begin{array}{l}-0.489^{a} \\
(0.150)\end{array}$ & 0.810 & 0.716 & 2 \\
\hline Sierra Leone & $\begin{array}{l}26.008 * \\
(0.048)\end{array}$ & $\begin{array}{l}8.427 \\
(0.219)\end{array}$ & $\begin{array}{l}17.581 \\
(0.090)\end{array}$ & $\begin{array}{l}8.427 \\
(0.219)\end{array}$ & $\begin{array}{l}-0.318^{b} \\
(0.143)\end{array}$ & 0.533 & 0.880 & 1 \\
\hline South Africa & $\begin{array}{l}24.221 * \\
(0.002)\end{array}$ & $\begin{array}{l}7.672 * \\
(0.006)\end{array}$ & $\begin{array}{l}16.550 * \\
(0.021)\end{array}$ & $\begin{array}{l}7.672 * \\
(0.006)\end{array}$ & $\begin{array}{l}-0.297^{a} \\
(0.106)\end{array}$ & 0.449 & 0.362 & 5 \\
\hline Sudan & $\begin{array}{l}16.019^{*} \\
(0.042)\end{array}$ & $\begin{array}{l}0.295 \\
(0.587)\end{array}$ & $\begin{array}{l}15.723 * \\
(0.029)\end{array}$ & $\begin{array}{l}0.295 \\
(0.587)\end{array}$ & $\begin{array}{l}-0.321^{b} \\
(0.145)\end{array}$ & 0.642 & 0.007 & 5 \\
\hline Togo & $\begin{array}{l}15.164 \\
(0.056)\end{array}$ & $\begin{array}{l}4.473 * \\
(0.034)\end{array}$ & $\begin{array}{l}10.690 \\
(0.170)\end{array}$ & $\begin{array}{l}4.473 * \\
(0.034)\end{array}$ & $\begin{array}{l}-0.539^{a} \\
(0.140)\end{array}$ & 0.298 & 0.000 & 1 \\
\hline Tunisia & $\begin{array}{l}24.363^{*} \\
(0.007)\end{array}$ & $\begin{array}{l}4.186^{*} \\
(0.041)\end{array}$ & $\begin{array}{l}20.177 * \\
(0.018)\end{array}$ & $\begin{array}{l}4.186^{*} \\
(0.041)\end{array}$ & $\begin{array}{l}-0.414^{a} \\
(0.123)\end{array}$ & 0.458 & 0.868 & 3 \\
\hline Uganda & $\begin{array}{l}13.721 \\
(0.200)\end{array}$ & $\begin{array}{l}3.906^{*} \\
(0.048)\end{array}$ & $\begin{array}{l}9.815 \\
(0.415)\end{array}$ & $\begin{array}{l}3.906^{*} \\
(0.048)\end{array}$ & $\begin{array}{l}-0.316^{b} \\
(0.151)\end{array}$ & 0.490 & 0.345 & 3 \\
\hline
\end{tabular}

Figures within parenthesis (.) are p-values under $\mathrm{H} 0: r \leq 0$ and $r \leq 1$; ${ }^{*}$ denotes rejection of the hypothesis at the 0.05 level. For the loading factors, figures within the parenthesis (.) are standard errors. LM (3) reports p-values of the third order LM test of the null of no serial correlation in VAR residuals. The column NOR reports p-values of Bera-Jarque normality tests of VAR residuals, Chi-squares distributed. The column LAG reports the VAR lag lengths used. Subscripts $a, b$, and $\mathrm{c}$ indicate significance at $1 \%, 5 \%$, and $10 \%$ respectively. 
For a valid normalization and error-correction representation, the associated loading factors must be negatively signed and significant. On this basis all of the countries can be normalized on $(\mathrm{I} / \mathrm{Y})$. The whole sample countries have their loading factors negatively signed; among them, 20 are significantly negative at $10 \%$ or better. Given the signs of loading factors and the existence of a single co-integrating vector, the parameters of our empirical model are then uniquely identified. LM tests show the absence of serial correlation in VAR residuals in all cases. The VAR residuals also pass normality tests for all cases. Thus, utilizing the ECM, we identify a long run investment rate relationship based on the saving rate.

Table 5 reports the normalized co-integrating coefficients (long run coefficients). The elasticity of (I/Y) with respect to $(\mathrm{S} / \mathrm{Y})$ is positive and significant for countries such as Botswana, Congo, Kenya, Mali, Mozambique, and Seychelles; and negative and significant for the remaining countries. The panel elasticity in absolute value (0.542) being too small relative to the most country specific coefficients, exhibits heterogeneity.

Table 5. Normalized co-integrating coefficients (standard error in parentheses)

\begin{tabular}{|c|c|c|c|c|c|c|c|c|c|}
\hline \multicolumn{10}{|c|}{ Section A: Country by country time series parameters } \\
\hline & $\mathrm{BEN}$ & BWA & CAM & $\mathrm{COG}$ & CIV & EGY & GAB & \multicolumn{2}{|c|}{ GHA } \\
\hline \multirow[t]{3}{*}{$\mathrm{S} / \mathrm{Y}$} & -0.879 & 0.476 & -0.879 & 0.436 & -0.897 & -0.177 & -0.163 & \multirow{2}{*}{\multicolumn{2}{|c|}{$\begin{array}{l}-0.972 \\
(0.288)\end{array}$}} \\
\hline & $(0.183)$ & $(0.221)$ & $(0.379)$ & $(0.338)$ & $(0.092)$ & $(0.142)$ & $(0.129)$ & & \\
\hline & KEN & MAD & MLI & MUS & $\mathrm{MCO}$ & $\mathrm{MOZ}$ & SEN & & \\
\hline \multirow[t]{4}{*}{$\mathrm{S} / \mathrm{Y}$} & 0.738 & -0.816 & 0.290 & -0.524 & -0.964 & 0.708 & -0.939 & \multirow{2}{*}{\multicolumn{2}{|c|}{$\begin{array}{l}0.922 \\
(0.590)\end{array}$}} \\
\hline & $(0.224)$ & $(0.226)$ & $(0.380)$ & $(0.184)$ & $(0.278)$ & $(0.688)$ & $(0.247)$ & & \\
\hline & SLE & ZAF & SDN & TGO & TUN & UGA & Section & B: & Panel \\
\hline & & & & & & & Results & & \\
\hline \multirow[t]{2}{*}{$\mathrm{S} / \mathrm{Y}$} & -0.919 & -0.844 & -0.978 & -0.844 & -0.888 & -0.231 & \multirow{2}{*}{\multicolumn{3}{|c|}{$\begin{array}{l}-0.542 \\
(0.662)\end{array}$}} \\
\hline & $(0.220)$ & $(0.113)$ & $(0.129)$ & $(0.165)$ & $(0.358)$ & $(0.103)$ & & & \\
\hline
\end{tabular}

Figures within parenthesis (.) are standard errors. The country mnemonics are: BEN = Benin; BWA = Botswana, $\mathrm{CGO}=$ Congo; $\mathrm{CIV}=$ Cote d'Ivoire, $\mathrm{EGY}=$ Egypt; $\mathrm{CAM}=$ Cameroon; $\mathrm{GAB}=$ Gabon; GHA = Ghana; KEN = Kenya; $\mathrm{MDG}=$ Madagascar; $\mathrm{MOZ}=$ Mozambique; $\mathrm{MLI}=$ Mali; $\mathrm{MUS}=$ Mauritius; $\mathrm{MCO}=$ Morocco; $\mathrm{SEN}=$ Senegal; SYC $=$ Seychelles, $\mathrm{SLE}=$ Sierra Leone; $\mathrm{ZAF}=$ South Africa; $\mathrm{SDN}=$ Sudan; $\mathrm{TUN}=$ Tunisia; $\mathrm{TGO}=$ Togo; UGA = Uganda.

It is important to note that the positively signed large coefficients $(0.922,0.738$, and 0.708$)$ of respectively Seychelles, Kenya, and Mozambique; contribute to reduce the size but not sufficient to turn the overall coefficient of the panel into positive $(-0.542)$. The entire existing panels tests suffer from this typical caveat results of some countries dominate the whole panel - and one of the contributions of our results is that they bring this issue to focus(Note 3). This further lends support to our preference to country-by-country (time series-based) results.

If we refer to the interpretation of the results of $\mathrm{F}-\mathrm{H}$, we have two distinct results as regards the developing countries. Indeed, taking into account country by country time series parameters, $\beta$ is higher for some countries and lower for other countries indicating respectively low and high mobility of capital. These results violate findings of F-H, which states that developing countries have a high mobility of capital that is to say low saving ratio. This violation holds on even if we refer to panel data results. The panel estimated saving retention coefficient $(-0.542)$ is relatively small (approximately a half of one) indicating a moderate degree of capital mobility and therefore for these countries, the Feldstein-Horioka puzzle does not hold valid. This suggests different groups of financial integration within African countries included in the sample.

\section{Conclusion}

This paper extends the literature on capital mobility. By pooling data, the estimated saving-retention coefficient is relatively small indicating that a moderate degree of capital mobility prevails and therefore for these countries, the Feldstein-Horioka puzzle does not hold valid. Because of the heterogeneity, when we use time series data and methods, along with the Dynamic Heterogeneous panel approach, the empirical findings reveal both lower and higher degrees of capital mobility for these countries. Again, the Feldstein-Horioka puzzle does not hold valid 
since it provides mixed results for the sample countries.

The economic and financial integration of these countries can be effective only if these countries decide to harmonize effectively their economic and financial policy. To reach integration ambition, they have to: - make economic reforms and structural adjustments, - fight against inflation by setting up flexible exchange rate system, - set up very effective capital control policies for fiscal and monetary policies. Raise such a challenge will enable those countries to: reduce the size of the non-traded sector, settle efficient financial mechanisms, provide better legal protection system for investors, reduce the magnitude of foreign aid, strengthen financial markets, and open without any restriction their economies. The success of maintaining better economic policies and therefore the exhibition of capital immobility depend above all on the discipline of policy makers and politicians of Africans countries.

\section{References}

Agenor, P-R. (2003). Benefits and Costs of International Financial Integration: Theory and Facts. The World Economy, 26, 8.

Alyousha, A., \& Tsoukis C. (2003). A Re-Examination of Saving-Investment Relationships: Cointegration, Causality, and International Capital Mobility. In G. Agiomirgianakis, et al. (Eds.), Advances in International Economics and Finance. London: Kluwer Academic Publishers.

Apergis, N., \& Tsoumas, C. (2009). A survey of the Feldstein-Horioka puzzle: What has been done and where we stand. Research in Economics, 63, 64-76. http://dx.doi.org/10.1016/j.rie.2009.05.001

Bahami-Oskooee, M., \& Chakrabarati, A. (2005). Openness, size and the saving-investment relationship. Economic Systems, 29, 289-293. http://dx.doi.org/10.1016/j.ecosys.2005.06.001

Bai, J., \& Ng S. (2004). A Panic Attack on Unit Roots and Cointegration. Econometrica, 72(4), 1127-1177.

Baltagi, H.B. (2003). Econometric Analysis of Panel Data. John Wiley \& Sons Ltd, New York.

Banerjee, A., \& P. Zanghieri (2003). A New Look at the Feldstein-Horioka Puzzle using an Integrated Panel. CEPII, 22.

Banerjee, A., Marcellino M., \& Osbat C. (2003). Some Cautions on the Use of Panel Methods for Integrated Series of Macro-Economic Data. European University Institute.

Bangake, C., \& Eggoh, J. (2010). International capital mobility in African countries: Do the legal origins matter? Economics Bulletin, 30, 1-10.

Baxter, M., \& Crucini M. (1993). Explaining saving-investment correlations. American Economic Review, 83, 416-436.

Bayoumi, T. (1990). Saving-investment correlations: immobile capital, government policy, or endogenous behavior. IMF Staff Papers, 37, 360-387.

Bayoumi, T., \& MacDonald R. (1995). Consumption, Income and International Capital Market Integration. IMF Staff Papers, 42, 552-576.

Blanchard, O., \& Giavazzi F. (2002). Current account deficits in the Euro Area: The end of the Feldstein-Horioka puzzle? Brookings Papers in Economic Activity, 2, 147-186.

Breitung, J. (2000). The Local Power of Some Unit Root Tests for Panel Data. In B.Baltagi (ed.), Non Stationary Panels, Panel Cointegration and Dynamic Panels: Advances in Econometrics, Vol. 15, 161-178. Jai Press, Amsterdam,

Casella, A. (1992). On Markets and Clubs: Economic and Political Integration of Regions with Unequal Productivity. The American Economic Review, 82(2), 115-121.

Chakrabarti, A. (2006). The Saving-Investment Relationship Revisited: new evidence from multivariate heterogeneous panel cointegration analyses. Journal of Comparative Economics, 34(2), 402-19.

Choi, I. (2001). Unit root tests for panel data. Journal of International Money and Finance, 20, 249-272. http://dx.doi.org/10.1016/S0261-5606(00)00048-6

Coakley, J., Fuertes A.-M., \& Spagnolo F. (2004). Is the Feldstein-Horioka Puzzle History? Manchester School, 72(5), 569-90.

Coakley, J., Hasan, F., \& Smith, R. (1999). Saving, investment and capital mobility in LDCs. Review of International Economics, 7, 632-640. http://dx.doi.org/ 10.1111/1467-9396.00188 
Coakley, J., Kulasi F., \& R. Smith. (1996). Current Account Solvency and the Feldstein-Horioka Puzzle. The Economic Journal, 106(436), 620-627.

Coakley, J., Kulasi F., \& Smith R. (1998). The Feldstein-Horioka puzzle and capital mobility: A review. International Journal of Finance and Economics, 3, 169-188.

Corbin, A. (2004). Capital Mobility and Adjustment of the Current Account Imbalances: a bounds testing approach to cointegration in 12 countries (1880-2001). International Journal of Finance and Economics, 9, 257-276.

De Wet, A. R., \& Koekemer. (2003). Capital Mobility in Sub-Saharan Africa: A Panel Data Approach. Working Paper 2002, University of Pretoria, 1-33.

De Wet, A.H., \& Van Eyden R. (2005). Capital Mobility in Sub-Saharan Africa: A Panel Data Approach. South African Journal of Economics, 73, 1-22.

Debaere, P., \& Demiroglu U. (1997). International Saving, Investment and Trade. Discussion Paper, 406.

Dooley, M., Frankel J., \& Mathieson D. (1987). International Capital Mobility in Developing Countries versus Industrialized Countries: What Do Savings-Investment Correlations Tell Us?. IMF Staff Papers, 34, 503-529.

Dornbusch, R. (1991). National Saving and International Investment: Comment. In B. Bernheim and J. B. Shoven (eds.), National Savings and Economic Performance. Chicago: University of Chicago Press, pp. 220-26.

Edison, H., Ricci L., \& Slok T. (2002). International Financial Integration and Economic growth. Journal of International Money and Finance, 21, 6.

Fattouh, B. (2005). Capital Mobility and Sustainability: evidence from US current account data. Empirical Economics, 30, 245-253.

Feldstein, M. (1983). Domestic saving and international capital movements in the long run and the short run. European Economic Review, 30, 735-752.

Feldstein, M., \& Bacchetta P. (1991). Domestic saving and international investment. In D. Bernheim and J. Shoven (eds.), National saving and economic performance. Chicago: Chicago University Press.

Feldstein, M., \& Horioka, C. (1980). Domestic saving and international capital flows. Economic Journal, 90, 314-329. http://dx.doi.org/10.2307/2231790

Frankel, J. (1986). International Capital Mobility and Crowding-Out in the U.S. Economy: Imperfect Integration of Financial Markets or of Goods Markets?. In R. Hafer (ed.), How Open is the U.S. Economy? Lexington: Lexington Books, pp. 33-67.

Frankel, J. (1991). Quantifying International Capital Mobility in the 1980s. In B. Bernheim and J. Shoven (eds.), National Saving and Economic Performanc. Chicago: University of Chicago Press.

Frankel, J. (1992). Measuring International Capital Mobility: A Review. The American Economic Review, 82(2), 197-202.

Frankel, J., \& MacArthur A. (1988). Political vs. currency premia in international real interest rate differentials. European Economic Review, 32, 1083-1121.

Genevieve Verdier. (2004). What Drives Long-Term Capital Flows? A Theoretical and Empirical Investigation. October 5, 2004, JEL classification numbers: F41, F43, O41.

Georgopoulos, G., \& Hejazi W. (2005). Feldstein-Horioka Meets a Time Trend. Economic Letters, 86(3), 353-357.

Ghosh, A. R., \& Ostry, J. D. (1995). The current account in developing countries: A perspective from the consumption smoothing approach. The World Bank Economic Review, 9, 305-333. http://dx.doi.org/10.1093/wber/9.2.305

Goldberg, L., James J., \& Okunev J. (2003). Has International Financial Integration Increased? Open Economies Review, 14(3), 299-317.

Haan, J., \& Siermann C. (1994). Saving, investment and capital mobility: a comment on Leachman (1991). Open Economies Review, 5, 5-17.

Haque, N., \& Montiel P. (1990). How Mobile is Capital in Developing Countries. Economics Letters, 33, 359-362. 
Haque, N., \& Montiel P. (1991). Capital Mobility in Developing Countries: Some Empirical Tests. World Development, 19(10), 1391-1398.

Ho, T.-W. (2002). A Panel Cointegration Approach to the Investment-saving Correlation. Empirical Economics, 27(1), 91-100.

Ho, T.W. (2002). The Feldstein-Horioka Puzzle revisited 2002. Journal of International Money and Finance, 21, 555-564.

Ho, T.-W. (2003). The Saving-retention Coefficient and Country-size: The Feldstein-Horioka Puzzle reconsidered. Journal of Macroeconomics, 25(3).

Hoffman, M. (2004). International Mobility in the Long-run and the Short-run: Can We Still Learn from Saving-Investment Data? Journal of International Money and Finance, 23, 113-131.

Hogendorn, C. (1998). Capital Mobility in Historical Perspective. Journal of Policy Modeling, 20(2).

Hussein, K.A., \& Mello L.R. (1999). International Capital Mobility in Developing Countries: Theory and Evidence. Journal of International Money and Finance, 18, 367-381.

Husted, S. (1992). The emerging U.S. current account deficit in the 1980s: a cointegration analysis. The Review of Economics and Statistics, 159-166.

Im, K. S., Pesaran, M. H., \& Shin, Y. (2003). Testing for unit roots in heterogeneous panels. Journal of Econometrics, 115, 53-74. http://dx.doi.org/10.1016/S0304-4076(03)00092-7

Im, K.S., Pesaran M.H., \& Shin Y. (1997). Testing for Unit Root in Heterogeneous Panels. University of Cambrdige. DAE Working Paper, No. 9526.

Isaksso, A. (2001). Financial liberalization, Foreign Aid, and Capital Mobility: Evidence from 90 Developing Countries. Journal of International Markets, Institutions, and Money, 11, 309-338.

Jansen, W. (1996). Estimating saving-investment correlations: evidence for OECD countries based on an error correction model. Journal of International Money and Finance, 5, 749-781.

Jansen, W. (1997). Can the intertemporal budget constraint explain the Feldstein-Horioka puzzle? Economics Letters, 56, 77-83.

Jansen, W. (2000). International capital mobility: Evidence from panel data. Journal of International Money and Finance, 19, 507-511.

Jansen, W., \& Schulze G. (1996). Theory-based Measurement of the Saving-Investment Correlation with an Application to Norway. Economic Inquiry, 34, 116-132.

Jansen, W.J. (1998). Interpreting Saving-Investment Correlations. Open Economies Review, 9, 205-217.

João Sousa Andrade. (2007). La thèse de Feldstein-Horioka: une mesure de la mobilité internationale du capital. PANOECONOMICUS, 1, str. 53-67 UDC 330.14.01, JEL: E21, E22, F21.

Kasuga, H. (2004). Saving-investment correlations in developing countries. Economics Letters, 83, 371-376. http://dx.doi.org/10.1016/j.econlet.2003.11.017

Kim, H., Oh K.-Y., \& Jeong C.-W. (2005). Panel Cointegration Results on International Capital Mobility in Asian Economies. Journal of International Money and Finance, 24(1), 71-82.

Kimball, M. (1990). Precautionary Saving in the Small and in the Large. Econometrica, 58(1), 53-73.

Koedijk, K., et al. (2002). The Cost of Capital in International Financial Markets: Local or Global? Journal of International Money and Finance, 21(6).

Krugman, P., \& Obstfeld M. (1994). International Economics: Theory and Policy. New York: HarperCollins.

Latsis, S. (1976). A Research Programm in Economics. In S. Latsis (ed.), Methods and Appraisal in Economics. Cambridge: C.U.P., pp. 1-41.

Lemmen, J., \& Eijffinger S. (1998). The Quantity Approach to Financial Integration: The Feldstein-Horioka Criterion Revisited (extended and updated version of the paper in Open Economics Review, Vol. 6, N.2, 1995,145-65). In J. Lemmen (ed.), Integrating Financial Markets in the European Union. Cheltenham: Edward Elgar.

Levin, A., \& Lin C.F. (1992). Unit Root Tests in Panel Data: Asymptotic and Finite Sample Properties. Discussion Paper 92-93, Department of Economics, University of California at San Diego. 
Levy, D. (1995). Investment-saving co-movement under endogenous fiscal policy. Open Economies Review, 6, 237-254.

Levy, D. (2003). Is the Feldstein-Horioka Puzzle really a Puzzle? In Agiomirgianakis, et al. (Eds.), Advances in International Economics and Finance. London: Kluwer Academic Publishers.

Mamingi, N. (1993). Savings-Investment Correlations and Capital Mobility in Developing Countries. The World Bank Policy Research Working Paper, 1211.

Mamingi, N. (1997). Saving-investment Correlations and Capital Mobility: The Experience of Developing Countries. Journal of Policy Modeling, 19(6), 605-616.

Mamingi, N. (1997). Savings-Investment Correlations in Developing Countries. Journal of Policy Modeling, 19 , 605-626.

Miller, S. (1988). Are Saving and Investment Co-integrated? Economics Letters, 27, 31-34.

Mishkin, F. (1986). Commentary on "International Capital Mobility and Crowdingout in the U.S. Economy: Imperfect Integration of Financial Markets or of Goods Markets?" The Federal Reserve Bank of St. Louis Review, December.

Montiel, P. (1994). Capital Mobility in Developing Countries: Some Measurement Issues and Empirical Estimates. World Bank Economic Review, 8, 311-350.

Moreno, R. (1997). Saving investment dynamics and capital mobility in the U.S. and Japan. Journal of International Money and Finance, 16, 837-863.

Muhittin Kaplan \& Hüseyin Kalyoncu. (2011). Measuring the Level of International Capital Mobility for MENA Countries. Journal of Economic and Social Studies, 1(1).

Muller, P. (2004). European Financial Market Integration. World Economics, 5(3).

Murphy, R. (1984). Capital Mobility and the Relationship between Savings and Investment Rates in OECD Countries. Journal of International Money and Finance, 3, 327-342.

Murphy, R. (1986). Productivity Shocks, Non-traded Goods and Optimal Capital Accumulation. European Economic Review, 30, 1081-1095.

Murthy, N. R. Vasudeva. (2009). The Feldstein-Horioka puzzle in Latin American and Caribbean countries: a panel cointegration analysis. Journal of Economics and Finance, 33(2), 176-188. http://dx.doi.org/10.1007/s12197-008-9051-5

Murthy, N.R.V. (2005). The Feldstein-Horioka Puzzle: New Evidence for the United States. The ICFAI Journal of Applied Economics, 4(1), 7-12.

Obsfeld, M., \& Rogoff K. (2000). The Six Puzzles in International Macroeconomics: Is There a Common Cause? NBER Working Paper, 7777.

Obstfeld, M. (1986). Capital mobility in the world economy: theory and measurement. Carnegie-Rochester Conference Series on Public Policy: Spring, pp. 1-24.

Obstfeld, M. (1994). International Capital Mobility in the 1990s. International Finance Discussion Papers, Board of Governors of the Federal reserves System, 472.

Ozmen, E. (2005). Macroeconomic and institutional determinants of current account deficits. Applied Economics Letters, 12, 557-560. http://dx.doi.org/10.1016/10.1080/13504850500120714

Ozmen, E., \& Parmaksiz K. (2003a). Exchange Rate Regimes and the Feldstein- Horioka Puzzle: The French Evidence. Applied Economics, 35(2).

Ozmen, E., \& Parmaksiz K. (2003b). Policy Regime Change and the Feldstein-Horioka Puzzle: The Uk Evidence. Journal of Policy Modeling, 25(2).

Parker, J., Jonathan A., \& Preston B. (2002). Precautionary Saving and Consumption Fluctuations. NBER Working Paper, 9196.

Payne, J., \& Kumazawa, R. (2006). Capital mobility and the Feldstein-Horioka puzzle: Reexamination of $\begin{array}{lllll}\text { less-developed } \quad \text { countries. The } & \text { Manchester }\end{array}$ http://dx.doi.org/10.1111/j.1467-9957.2006.00512.x

Payne, J., \& Mohammadi H. (2006). Capital Mobility and Savings-Investment Correlations: panel data evidence from transition economies. Applied Economic Letters, 13(10), 611-613. 
Payne, J.E., \& Kumazawa R. (2005). Capital Mobility, Foreign Aid, and Openness: Further Panel Data Evidence from Sub-Saharan Africa. Journal of Economics and Finance, 29(1), 122-126.

Pedroni, P. (1999). Critical Values of Cointegration Tests in Heterogeneous Panels with Multiple Regressors. Oxford Bulletin of Economics and Statistics, 61, 653-670.

Pedroni, P. (2000). Fully Modified OLS for Heterogeneous Cointegrated Panels. In Baltagi, B., C.D. Kao (Eds.), Advances in Econometrics, Nonstationary Panels, Panel Cointegration and Dynamic Panels, Elsevier Science, New York, 93-130.

Pedroni, P. (2001). Purchasing Power Parity Tests in Cointegrated Panels. The Review of Economics and Statistics, 83, 727-731. Quantitative Micro Software (2004). EVIEWS 5, Irvine, California.

Popper, H. (1990). International capital mobility: direct evidence from long-term currency swaps. International Finance, Board of Governors, Federal Reserve System, 386.

Popper, K. (2002). Conjectures and Refutations (1963). London: Routledge.

Rocha, F. (2000). Capital Mobility in Developing Countries: Evidence from Panel Data. Universidade de Sao Paulo, Brazil, Department of Economics Working Paper.

Rocha, F., \& Zerbini B. (2000). Using a panel structure to discuss the Feldstein-Horioka puzzle in developing countries. Universidade de São Paulo, S. Paulo and MFS Investment Management, Boston.

Sachs, J. (1981). The current account and macroeconomic adjustment. Brookings Papers on Economic Activity, 1, 201-68.

Sachsida, A., \& Caetano M. (2000). The Feldstein.Horioka puzzle revisited. Economics Letters, 68, 85-88.

Schneider, B. (2004). Saving-Investment Correlations and Capital Mobility in Developing Countries with Special Reference to India 1999. Indian Journal for Research on International Economic Relations, Working Paper 48.

Sinha, T., \& Sihna, D. (2004). The mother of all puzzles would not go away. Economics Letters, 82, 259-267. http://dx.doi.org/10.1016/j.econlet.2003.06.002

Sinn, S. (1992). Saving-Investment Correlations and Capital Mobility: On the Evidence form Annual Data. Economic Journal, 102, 1171-1183.

Summers, L. (1988). Tax Policy and International Competitiveness. In J. Frenkel (Ed.), International Aspects of Fiscal Policies. Chicago: University of Chicago Press, pp. 349-86.

Taylor, A. (1996). International Capital Mobility in History: the Saving-Investment Relationship. NBER Working Paper, 5743.

Tesar, L. (1991). Savings, Investment, and International Capital Flows. Journal of International Economics, 31, 55-78.

Tobin, J. (1983). Domestic Savings and International Capital Movements in the Long-Run and Short-Run. European Economic Review, 21, 153-56.

Vamvakidis, A.A., \& Wacziarg R. (1998). Developing Countries and the Feldstein- Horioka Puzzle. International Monetary Fund Working Paper 98/2, 1-24. World Bank (2003). African Data Base, 2003.

Vasudeva Murthy N. R. (2005). Capital Mobility in African Countries: Evidence from Panel Data Cointegration Tests. Indian Journal of Economics and Business, 4(2), 257-266.

Verdier, G. (2003). What Drives Long-term Capital Flows? A Theoretical and Empirical Investigation. Department of Economics, Texas A\&M University.

Westerlund, J. (2006). Testing for Panel Cointegration with Multiple Sctructural Breaks. Oxford Bulletin of Economics and Statistics, 68(1), 101-132.

Westphal, U. (1983). Comments on Domestic Saving and International Capital Movements in the Short-run and in the Long-run. European Economic Review, 21, 157-159.

Wheatley, S. (1988). Some Tests of International Equity Integration. Journal of Financial Economics, 21(2), 177-212.

Wong, D. Y. (1990). What does saving-investment relationship tell us about capital mobility? Journal of International Money and Finance, 9, 60-74. http://dx.doi.org/10.1016/10.1016/0261-5606(90)90005-K 


\section{Notes}

Note 1. In our view, 40 years at least provide sufficient time length to capture the long-run relationship between investment rate and saving rate.

Note 2. Johansen (1992) suggests that the lag length in the VAR should be specified whereby the VAR residuals are rendered uncorrelated. Selection of lag length based on information criteria may not be adequate to render the VAR residual uncorrelated (Cheung and Lai, 1993). Hence, we specify lag length based on the test of serial correlation in VAR residuals.

Note 3. Panel unit root tests, panel co-integration tests (dynamic heterogeneous or otherwise) and traditional (OLS- and/or IV- based) panel tests all suffer from this problem. 